\title{
Explaining the influence behind Malaysia's pharmacy students' career choices within the pharmaceutical industry
}

Nur Farah Diyaanah Ibrahim ${ }^{1}$, Ernieda Hatah ${ }^{1}$ (D), Siti Azdiah Abd Aziz ${ }^{1}$, Shairyzah Ahmad Hisham², Irma Wati Ngadimon ${ }^{3}$, Muhammad Junaid Farukh ${ }^{4}$, Mohd Fadli Mohd Asmadi ${ }^{5}$

\footnotetext{
${ }^{1}$ Faculty of Pharmacy, Universiti Kebangsaan Malaysia, Kuala Lumpur, Malaysia

2 Faculty of Pharmacy, University of Cyberjaya, Selangor, Malaysia

${ }^{3}$ Faculty of Pharmacy, MAHSA University, Selangor, Malaysia

${ }^{4}$ Faculty of Pharmaceutical Sciences, UCSI University, Kuala Lumpur, Malaysia

${ }^{5}$ School of Pharmacy, Management and Science University, Selangor, Malaysia
}

Keywords
Career
Education
Pharmaceutical industry
Pharmacy
Student
Correspondence
Ernieda Hatah
Faculty of Pharmacy
Universiti Kebangsaan Malaysia
Jalan Raja Muda Abdul Aziz
53000 Kuala Lumpur
Malaysia
ernieda@ukm.edu.my

\section{Keywords}

Pharmaceutical industry

Pharmacy

Correspondence

Ernieda Hatah

Faculty of Pharmacy

Jalan Raja Muda Abdul Aziz

Malaysia

ernieda@ukm.edu.my

\begin{abstract}
Objective: The pharmaceutical industry has been portrayed as a promising sector for pharmacy graduates. Nonetheless, little is known about pharmacy students' preferences, knowledge, and attitudes toward careers in the pharmaceutical industry, as well as the factors that may influence them. Method: A self-developed questionnaire was administered to pharmacy students in public and private universities in Malaysia from October to November 2018 via online platforms. Results: Only $38.8 \%$ out of 433 students who completed the survey stated their preference for working in the pharmaceutical industry. The mean (SD) of knowledge, perceived syllabus, and attitudes related to pharmaceutical industry career preferences were 8.73 (1.77) (full score of 12), 28.50 (5.83) (full score of 40), and 30.59 (4.32) (full score of 50), respectively. Students from private universities, those in years one and three of study, and those with higher attitude scores were more likely to choose the pharmaceutical industry as their career option. Conclusion: Increasing exposure to pharmaceutical industry careers that involve patient contact and clinical knowledge application is needed to improve students' attitudes toward pursuing a career in this field.
\end{abstract}

\section{Introduction}

Due to the increased demand for pharmaceutical products and market growth worldwide, the pharmaceutical industry has been depicted as a promising sector for pharmacy graduates. The pharmaceutical industry is responsible for the development, production and marketing of medications which includes biological and pharmaceutical products as well as botanical drugs and herbs (Los Angeles Research Group, 2018). In general, pharmacists in pharmaceutical industries are responsible for ensuring that medicine for public use is safe, effective, and of good quality. The scope of pharmacy practice in pharmaceutical industries includes conducting research and drug development, manufacturing and quality assurance, providing drug information, patent applications and drug registrations, conducting clinical trials, post-marketing surveillance, sales, marketing, and management (World Health Organization, 1994; Josse et al., 2019).

The pharmaceutical market was valued to be worth about 1.25 trillion United States Dollars (USD) in 2019 (Mikulic, 2020). As a result of this, it was predicted that there would be a $14 \%$ increase in overall jobs for pharmacists between 2012 and 2022, compared to $11 \%$ for all other careers (Farnen, 2020). Although the job opportunities in the pharmaceutical industries are 
promising, studies reported that there was a lack of interest among pharmacy students to pursue a career in this field. Studies conducted in the United Kingdom (Wilson et al., 2006), Nigeria (Ubaka et al., 2013), Saudi Arabia (Saleh et al., 2015; Mahmoud, 2018), Japan (Nakagomi et al., 2016) and Malaysia (Hasan et al., 2010) found that working in hospitals and community pharmacies were preferred career options. A recent study in the United Kingdom reported an improvement in the preference for a career in the pharmaceutical industry, from being ranked sixth and ninth in 2010 to third in 2016 (Hanna et al., 2016). However, the study did not investigate the factors that may influence this improvement. Interestingly, a study conducted among pharmacy students in a university in India reported a combined percentage of pharmacy students' having a $41.8 \%$ preference for a career in both research and development and industry versus a $22.5 \%$ preference for a career in hospital/clinical/community pharmacy (Berhanu et al., 2019). Nevertheless, the study also did not explore the factors that may influence the greater preference for a career in research and development and the pharmaceutical industry other than generic consideration of overall job opportunities in the field.

In Malaysia, the pharmaceutical industry was reported as having a steady market growth of between $8 \%$ and $10 \%$ annually in 2015, with approximately 264 local and multinational registered manufacturing companies (Malaysian Investment Development Authority, 2016). They were reported as having the capacity to produce a wide range of pharmaceutical products such as generic drugs, over-the-counter products, traditional medicines, herbal products, and many others for both local and overseas supply (Malaysian Investment Development Authority, 2016). Currently, the Malaysian pharmaceutical market is estimated at more than Ringgit Malaysia (RM) 13 million in the country's gross national income and is expected to have growing job opportunities in the future (Performance Management \& Delivery Unit, 2013; Pharmaceutical Association of Malaysia, 2016). Nevertheless, the industry has reported facing a shortage of local, expert personnel who are willing to work in the sector (Malaysian Investment Development Authority, 2018). According to the report by the Malaysian Institute of Labour Market Information and Analysis in 2013 on manpower requirement in the healthcare sub-sectors in Malaysia, the critical categories of healthcare personnel in pharmaceutical manufacturing includes pharmacists (ILMA, 2013).

In previous studies, pharmacy students' career choices were reported to be influenced by several factors such as knowledge and experiential learning in various related pharmacy environments, the pharmacy degree curriculum, and previous experience working in the different sectors (Wilson et al., 2006). Students were also reported to have chosen their career path based on considerations of job security, having direct contact with patients, job advancement opportunities, salary (Ubaka et al., 2013; Hanna et al., 2016), benefits, and geographical location (Hasan et al., 2010). However, there have not been any studies that have investigated factors that may influence pharmacy students' career preferences in the pharmaceutical industry. Hence, this study aims to explore potential factors that may explain pharmacy students' career preference in pharmaceutical industries, such as knowledge, attitudes, demographic factors, including the type of institutions and others.

\section{Methods}

This study was conducted as a cross-sectional, selfadministered survey among pharmacy students in Malaysia. Pharmacy students at public and private universities who met the following criteria were invited to participate: in year one to four of a pharmacy degree, Malaysian citizen, and able to provide informed consent. Students who had family members working as pharmacists in the pharmaceutical industry or who had incomplete surveys that were missing more than $20 \%$ of data were excluded. The survey was distributed between October and November 2018 using snowball sampling methods via electronic mail and a Google survey. It was also shared on various online platforms such as the Malaysian Pharmacy Student's Association website, social media such as Facebook, and the WhatsApp application. To increase the response rate, academics from the universities were also invited to collaborate by sharing the survey link with their students. Participation was voluntary, and no incentive was provided. The students were informed of their rights and that continuing to answer the online survey indicated their agreement to participate.

The questionnaire was developed in English based on the literature review of previous studies and input from academics in pharmacy programmes who were experts in the field (Kirby-Smith et al., 2007; Savage et al., 2009; Hasan et al., 2010). There were five sections in the survey: (1) student's demographics and characteristics; (2) part 1: career preferences that asked the students to choose three out of eight career options that they most preferred, and part 2: 8-items on factors that influence students' job considerations such as salary and work-life balance with answer options ranging from "not at all important" to "very important"; (3) 12items on knowledge related to the scope of pharmacists in the pharmaceutical industry with "yes," "no," and "not sure" options; (4) 10-items on attitudes 
toward a career in pharmaceutical industries with 5items Likert scale answer options of "strongly disagree" to "strongly agree"; and (5) 8-items on overall perceptions of the university's syllabus, programmes, and student services related to a career choice in the pharmaceutical industry with a 5-item Likert scale with answer options ranging from "strongly disagree" to "strongly agree" and additional answer option of "not sure". The latter was provided so that respondents could respond with an answer that was true to their experience. If they were unsure about the perceived syllabus asked, they could select "not sure" rather than "neutral," which refers to respondents not taking a position when they have not formed an opinion about it. A score between one and five was given to the most negative and most positive responses, respectively. In section 3, students' knowledge on the job scope related to the pharmaceutical industry was evaluated, with each correct answer receiving one mark and wrong or "not sure" options receiving zero. Sections 3, 4, and 5 were calculated by adding the scores of each item, and the total marks for the sections were 12,50 , and 40 .

Prior to data collection, a pilot study was conducted with 20 students to test the face validity and reliability of the questionnaire. Students' feedback was taken into consideration, and appropriate changes were made accordingly. On average, the completion time ranged between 10 and 15 minutes. Internal consistency for individual subscales was assessed using Cronbach's alpha and the results were as follows: section 2 part 2: $\alpha=0.786$; section 3: $\alpha=0.723$; section 4: $\alpha=0.801$; section 5 part $1: \alpha=0.955$ and part $2: \alpha=$ 0.895 . The Statistical Program Social Sciences (SPSS) version 23.0 was utilised to analyse the data. Students' demographic characteristics and responses for each section were summarised using descriptive statistics, while the relationship between students' knowledge, attitudes, and syllabus scores was examined using Spearman's rank correlation test. Factors that may influence students' preferences in pursuing careers in the pharmaceutical industry were modelled using binary logistic regression. A univariate analysis was conducted prior to the multivariate analysis to choose the variables to be included in the final modelling analysis, and only variables with a $p$-value of less than 0.25 were included in the final model (Bursac et al., 2008). The final model was determined using the backward elimination method, and a variable with a $p$ value of less than 0.05 was considered as having a significant influence on students' preferences toward pursuing a career in the pharmaceutical industry.

Ethical approval for this study was obtained from the Research Ethics Committee of Universiti Kebangsaan, Malaysia (UKMPPI/111/8/JEP-2018-401).

\section{Results}

A total of 433 students from five public and ten private universities responded to the survey. The mean (SD) age of students was 21.9 (1.49) and ranged between 19 and 33 years. The majority of the students were female $(n=345,79.7 \%)$ and of Malay ethnicity $(n=220,50.8 \%)$. A total of 252 students (58.2\%) were from private universities; the rest were from public universities $(n=181,41.8 \%)$. The majority $(n=221,51.0 \%)$ were in their final year of study and had a current cumulative grade point average (CGPA) of between 2.67 and 3.66 ( $n=335,77.4 \%)$. The majority ( $n=207,47.8 \%)$ had received study loans from the National Higher Education Fund, followed by self-funding $(n=112$, $25.9 \%)$. The majority $(n=358,82.7 \%)$ also stated that they had a compulsory pharmaceutical industry placement as part of the graduation requirement set by their universities, with a mean (SD) duration of 34.79 (72.01) days. The sum of the students' demographic characteristics is presented in Table I.

Table I: Demographic characteristics of students that participated in the study $(n=433)$

\begin{tabular}{|c|c|c|}
\hline Variables & n (\%) & Mean \pm SD \\
\hline Age (years) & & 21.91 (1.49) \\
\hline \multicolumn{3}{|l|}{ Gender } \\
\hline Male & $88(20.3)$ & \\
\hline Female & 345 (79.7) & \\
\hline \multicolumn{3}{|l|}{ Ethnicity } \\
\hline Malay & $220(50.8)$ & \\
\hline Chinese & 164 (37.9) & \\
\hline Indian & $37(8.5)$ & \\
\hline Others & $12(2.8)$ & \\
\hline \multicolumn{3}{|l|}{ Type of institution } \\
\hline Public & $181(41.8)$ & \\
\hline Private & $252(58.2)$ & \\
\hline \multicolumn{3}{|l|}{ Year of study } \\
\hline 1 & $24(5.5)$ & \\
\hline 2 & $45(10.4)$ & \\
\hline 3 & $143(33.0)$ & \\
\hline 4 & $221(51.0)$ & \\
\hline \multicolumn{3}{|l|}{ Current CGPA } \\
\hline$<2.66$ & $15(3.5)$ & \\
\hline $2.67-3.66$ & 335 (77.4) & \\
\hline$>3.66$ & $83(19.2)$ & \\
\hline \multicolumn{3}{|c|}{$\begin{array}{l}\text { Source of funding for tuition } \\
\text { fees }\end{array}$} \\
\hline PTPTN & $207(47.8)$ & \\
\hline PSD scholarship & $45(10.4)$ & \\
\hline MARA scholarship & $33(7.6)$ & \\
\hline Parents & $112(25.9)$ & \\
\hline Others & $36(8.3)$ & \\
\hline
\end{tabular}


Table I: Demographic characteristics of students that participated in the study $(n=433)$ (continued)

\begin{tabular}{|c|c|c|}
\hline Variables & n (\%) & Mean \pm SD \\
\hline \multicolumn{3}{|l|}{$\begin{array}{l}\text { Does placement at pharmaceutical } \\
\text { industry is compulsory in student's } \\
\text { academic program? }\end{array}$} \\
\hline Yes & $358(82.7)$ & \\
\hline No & 75 (17.3) & \\
\hline $\begin{array}{l}\text { Duration of industry placement } \\
\text { (days) }\end{array}$ & & $34.79(72.01)$ \\
\hline \multicolumn{3}{|l|}{ Preferred career choice } \\
\hline Hospital pharmacist & $344(79.4)$ & \\
\hline Community pharmacist & $276(63.7)$ & \\
\hline Primary health care pharmacist & $210(48.5)$ & \\
\hline Pharmaceutical industries & $168(38.8)$ & \\
\hline Regulatory bodies & $84(19.4)$ & \\
\hline Academia & $83(19.2)$ & \\
\hline Research and development & $56(12.9)$ & \\
\hline Other non-pharmacy related job & $52(12.2)$ & \\
\hline
\end{tabular}

The most preferred career choices selected were hospital pharmacies $(n=344,79.4 \%)$, community pharmacies $(n=276,63.7 \%)$, and primary healthcare facilities $(n=210,48.5 \%)$. The remaining were pharmaceutical industries ( $n=168,38.8 \%)$, academia $(n=83,19.2 \%)$, research and development $(n=56$, $12.9 \%)$, regulatory bodies $(n=84,19.4 \%)$, and other non-pharmacy related jobs ( $n=52,12.2 \%)$. When the factors that may affect students' career considerations were evaluated, a work-life balance had the highest mean (SD) score of 4.53 (0.638), while a flexible work schedule had the lowest mean (SD) score of 4.14 (0.733). Detailed information on the factors that affected job consideration is presented in Table II. In the current study, the mean (SD) of students' knowledge related to a career in the pharmaceutical industry was 8.73 (1.77) from a total score of 12 . The majority knew that pharmacists work in related areas in pharmaceutical industries such as manufacturing, quality assurance, pharmaceutical product distribution, research and development, and others. Nevertheless, only 214 (49.4\%) knew that working in medical affairs was a career option (Table III).

Table II: Factors that affect pharmacy students' preferences relating to future jobs

\begin{tabular}{|c|c|c|c|c|c|c|}
\hline \multirow[t]{2}{*}{ Variables } & \multicolumn{5}{|c|}{ Number of respondents, $\mathrm{n}(\%)$} & \multirow[b]{2}{*}{ Mean (SD) } \\
\hline & $\begin{array}{c}\text { Not at all } \\
\text { important }\end{array}$ & $\begin{array}{c}\text { Low } \\
\text { importance }\end{array}$ & Neutral & Important & Very important & \\
\hline Salary & $1(0.2)$ & $5(1.2)$ & $23(5.3)$ & $244(56.4)$ & $160(37.0)$ & $4.29(0.639)$ \\
\hline Flexible work schedule & 0 & $7(1.6)$ & $69(15.9)$ & $213(49.2)$ & $144(33.3)$ & $4.14(0.733)$ \\
\hline Rewards and benefits & $1(0.2)$ & $7(1.6)$ & $58(13.4)$ & $227(52.4)$ & $140(32.3)$ & $4.15(0.722)$ \\
\hline Geographical location & 0 & $8(1.8)$ & 47 (10.9) & $218(50.3)$ & $160(37.0)$ & $4.22(0.709)$ \\
\hline Advancement opportunity & 0 & $2(0.5)$ & $51(11.8)$ & $207(47.8)$ & $173(40.0)$ & $4.27(0.680)$ \\
\hline Work environment & 0 & 0 & $23(5.3)$ & $169(39.0)$ & $241(55.7)$ & $4.50(0.598)$ \\
\hline Work-life balance & 0 & $3(0.7)$ & $25(5.8)$ & $144(33.3)$ & $261(60.3)$ & $4.53(0.638)$ \\
\hline Job security & 0 & $3(0.7)$ & $25(5.8)$ & $155(35.8)$ & $250(57.7)$ & $4.51(0.639)$ \\
\hline
\end{tabular}

Table III: Summary of student's knowledge related to career options in the pharmaceutical industry

\begin{tabular}{|c|c|c|c|}
\hline Variables & Correct answer & $\begin{array}{c}\text { Number of respondents that } \\
\text { selected a correct answer, } \\
n(\%)\end{array}$ & $\begin{array}{c}\text { Number of respondents that } \\
\text { selected a wrong answer/not } \\
\text { sure, } n(\%)\end{array}$ \\
\hline Research and development & Yes & $394(91.0)$ & $39(9.0)$ \\
\hline Medical affairs & Yes & $214(49.4)$ & $219(50.6)$ \\
\hline Manufacturing & Yes & $421(97.2)$ & $12(2.8)$ \\
\hline Quality assurance & Yes & $421(97.2)$ & $12(2.8)$ \\
\hline Accounting & No & $138(31.9)$ & $295(68.1)$ \\
\hline Pharmaceutical product distribution & Yes & $399(92.1)$ & 34 (7.9) \\
\hline Clinical trial & Yes & $354(81.8)$ & $79(18.2)$ \\
\hline Regulatory affairs & Yes & $329(76.0)$ & $104(24.0)$ \\
\hline Logistic & Yes & $336(77.6)$ & $97(22.4)$ \\
\hline Human resource & No & $71(16.4)$ & $362(83.6)$ \\
\hline Pharmacovigilance & Yes & $328(75.8)$ & $105(24.2)$ \\
\hline Sales and marketing & Yes & $374(86.4)$ & $59(13.6)$ \\
\hline
\end{tabular}


The students' mean attitude score (SD) toward pursuing a career in the pharmaceutical industry was 30.59 (4.32), with a full score of 50 . The majority $(n=$ 298, 68.5\%) "agreed" and "strongly agreed" that the pharmaceutical industry offers a good salary, does not have a close working environment with patients $(\mathrm{n}=$ $279,64.4 \%)$, and has good career advancement potential $(n=251,58.0 \%)$. About $41.6 \%(n=180)$ were "neutral" in their beliefs that the pharmaceutical industry does not provide a good work-life balance, it is difficult to secure a job $(n=183,42.3 \%)$, it does not utilise clinical knowledge ( $n=139,32.1 \%)$, and has strict job requirements $(n=163,37.6 \%)$. A lesser number ( $n=171,39.5 \%)$ "agreed" and "strongly agreed" that a higher CGPA score is needed to secure a job in the pharmaceutical industry, and 184 (42.5\%) "agreed" or "strongly agreed" that pharmaceutical sciences are difficult subjects to comprehend (Table IV).

Table IV: Summary of students' attitudes toward pursuing a career in the pharmaceutical industry

\begin{tabular}{|c|c|c|c|c|c|}
\hline \multirow[t]{2}{*}{ Variables } & \multicolumn{5}{|c|}{ Number of respondents, $n(\%)$} \\
\hline & $\begin{array}{l}\text { Strongly } \\
\text { disagree }\end{array}$ & Disagree & Neutral & Agree & $\begin{array}{l}\text { Strongly } \\
\text { agree }\end{array}$ \\
\hline The pharmaceutical industry offers a good salary & $4(0.9)$ & $10(2.3)$ & $121(27.9)$ & $218(50.3)$ & $80(18.5)$ \\
\hline $\begin{array}{l}\text { There is no work-life balance in the pharmaceutical } \\
\text { industry. }\end{array}$ & $15(3.5)$ & $154(35.6)$ & $180(41.6)$ & $74(17.1)$ & $10(2.3)$ \\
\hline $\begin{array}{l}\text { The pharmaceutical industry has a harsh working } \\
\text { environment for pharmacists. }\end{array}$ & $22(5.1)$ & $167(38.6)$ & $150(34.6)$ & $80(18.5)$ & $14(3.2)$ \\
\hline $\begin{array}{l}\text { The pharmaceutical industry offers good career } \\
\text { advancements such as promotions and training. }\end{array}$ & $8(1.8)$ & $24(5.5)$ & $150(34.6)$ & $197(45.5)$ & $54(12.5)$ \\
\hline $\begin{array}{l}\text { It is difficult to secure a job in the pharmaceutical } \\
\text { industry. }\end{array}$ & $15(3.5)$ & $87(20.1)$ & $183(42.3)$ & $112(25.9)$ & $36(8.3)$ \\
\hline $\begin{array}{l}\text { I need to have a high CGPA score to be able to secure a } \\
\text { job in the pharmaceutical industry. }\end{array}$ & $18(4.2)$ & $77(17.8)$ & $167(38.6)$ & $127(29.3)$ & $44(10.2)$ \\
\hline $\begin{array}{l}\text { Working in the pharmaceutical industry would not } \\
\text { allow me to work in close contact with patients. }\end{array}$ & $12(2.8)$ & $47(10.9)$ & 95 (21.9) & $166(38.3)$ & $113(26.1)$ \\
\hline $\begin{array}{l}\text { Pharmaceutical sciences are difficult subjects to } \\
\text { comprehend. }\end{array}$ & $15(3.5)$ & $71(16.4)$ & $163(37.6)$ & $148(34.2)$ & $36(8.3)$ \\
\hline $\begin{array}{l}\text { I feel that it is a waste that I cannot utilise my clinical } \\
\text { knowledge should I work in the pharmaceutical } \\
\text { industry. }\end{array}$ & $40(9.2)$ & $116(26.8)$ & $139(32.1)$ & $104(24.0)$ & $34(7.9)$ \\
\hline $\begin{array}{l}\text { I feel that working in the pharmaceutical industry does } \\
\text { not suit me as it has strict job requirements as it needs } \\
\text { pharmacists to work in a highly regulated environment } \\
\text { such as production sites or clean rooms. }\end{array}$ & $29(6.7)$ & $120(27.7)$ & $163(37.6)$ & $86(19.9)$ & $35(8.1)$ \\
\hline
\end{tabular}

The students' mean scores (SD) on perceptions related to the overall syllabus, university programmes, and student support services related to a career in the pharmaceutical industry was 28.50 (5.38) out of 40 . A significant number "agreed" and "strongly agreed" those appropriate credit hours were allocated for pharmaceutical industry subjects in their degree programmes ( $n=275,63.5 \%$ ), their syllabus included visits to pharmaceutical industry sites ( $n=282,65.1 \%$ ), they had an adequate industrial placement duration ( $\mathrm{n}$ $=221,51 \%$ ), were provided with careers talks ( $n=283$, $65.3 \%$ ) and career fairs ( $n=207,47.8 \%)$, and had access to a counsellor who offered advice $(n=218,50.3 \%)$ (Table V).

There was a significant weak correlation between students' scores on their perceived syllabus and knowledge of career opportunities in the pharmaceutical industry $(r=0.123, p<0.05)$. However, there was no significant correlation between students' knowledge and attitude scores $(p>0.05)$. When factors that influence students' preferences toward pursuing a career in the pharmaceutical industry were modelled, students from private universities were found to be 2.08 times more likely to choose a career in the pharmaceutical industry than those from public universities $(\mathrm{OR}=2.076,95 \% \mathrm{Cl}=1.320$ and $3.265, p=$ 0.002 ). The first- and third-year students were 3.95 and 1.98 times more likely to choose working in the pharmaceutical industry than final year students (OR = 3.953, $95 \% \mathrm{Cl}=1.511$ and 10.337, $p=0.005 ; \mathrm{OR}=1.980$, $95 \% \mathrm{Cl}=1.243$ and 3.154, $p=0.004$, respectively). In addition, an increase by one point in the students' attitude scores increased the likelihood of them having a preference toward pursuing a career in the pharmaceutical industry by $19 \%(\mathrm{OR}=1.196,95 \% \mathrm{Cl}=$ 1.130 and 1.266 , respectively; $p<0.001)$. The final model is presented in Table VI. 
Table V: Summary of students' perceptions toward their syllabus, university programmes and support services related to careers in pharmaceutical industries

\begin{tabular}{|c|c|c|c|c|c|c|}
\hline \multirow[t]{2}{*}{ Variables } & \multicolumn{6}{|c|}{ Number of respondents, $\mathrm{n}(\%)$} \\
\hline & $\begin{array}{l}\text { Strongly } \\
\text { disagree }\end{array}$ & Disagree & Neutral & Agree & $\begin{array}{l}\text { Strongly } \\
\text { agree }\end{array}$ & Not sure \\
\hline $\begin{array}{l}\text { There are appropriate credit hours allocated for } \\
\text { pharmaceutical industry subjects in my degree } \\
\text { programme. }\end{array}$ & $7(1.6)$ & $23(5.3)$ & $101(23.3)$ & $195(45.0)$ & $80(18.5)$ & $27(6.2)$ \\
\hline $\begin{array}{l}\text { In my degree programme, the syllabus includes } \\
\text { visits to the pharmaceutical industry. }\end{array}$ & $22(5.1)$ & $46(10.6)$ & $59(13.6)$ & $156(36.0)$ & $126(29.1)$ & $24(5.5)$ \\
\hline $\begin{array}{l}\text { There is an adequate duration of industrial } \\
\text { placement during my degree study. }\end{array}$ & $23(5.3)$ & $54(12.5)$ & $94(21.7)$ & $137(31.6)$ & $84(19.4)$ & $41(9.5)$ \\
\hline $\begin{array}{l}\text { During my study, career talks about the } \\
\text { pharmaceutical industry are provided to the } \\
\text { students. }\end{array}$ & $11(2.5)$ & $28(6.5)$ & $84(19.4)$ & $163(37.6)$ & $120(27.7)$ & $27(6.2)$ \\
\hline $\begin{array}{l}\text { During my study, career fairs about the } \\
\text { pharmaceutical industry are provided to } \\
\text { students. }\end{array}$ & $23(5.3)$ & $58(13.4)$ & $113(26.1)$ & $127(29.3)$ & $80(18.5)$ & $32(7.4)$ \\
\hline $\begin{array}{l}\text { There are leaflets, brochures and/or flyers } \\
\text { containing information about careers in the } \\
\text { pharmaceutical industry distributed to students. }\end{array}$ & $28(6.5)$ & $87(20.1)$ & $136(31.4)$ & $94(21.7)$ & $50(11.5)$ & $38(8.8)$ \\
\hline $\begin{array}{l}\text { My university has a partnership with some } \\
\text { pharmaceutical industries. }\end{array}$ & $16(3.7)$ & $22(5.1)$ & $70(16.2)$ & $139(32.1)$ & $116(26.8)$ & $70(16.2)$ \\
\hline $\begin{array}{l}\text { In my university, there is a counsellor or mentor } \\
\text { that provides advice on career choices to the } \\
\text { students. }\end{array}$ & $25(5.8)$ & $28(6.5)$ & $102(23.6)$ & $134(30.9)$ & $84(19.4)$ & $60(13.9)$ \\
\hline
\end{tabular}

Table VI: Factors that may influence students' preference in pursuing a career in the pharmaceutical industry

\begin{tabular}{|c|c|c|c|c|c|c|c|c|}
\hline & \multicolumn{4}{|c|}{ Univariate analysis } & \multicolumn{4}{|c|}{ Binary logistic regression } \\
\hline & $\begin{array}{c}\text { Crude } \\
\text { OR }\end{array}$ & $95 \% \mathrm{Cl}$ & $\begin{array}{c}\text { Wald's } x^{2} \\
\text { (df) }\end{array}$ & $\begin{array}{c}p- \\
\text { value }\end{array}$ & $\begin{array}{c}\text { Adjusted } \\
\text { OR }\end{array}$ & $95 \% \mathrm{Cl}$ & $\begin{array}{c}\text { Wald's } x^{2} \\
\text { (df) }\end{array}$ & $\begin{array}{c}p- \\
\text { value }\end{array}$ \\
\hline Male & 1.00 & & & & & & & \\
\hline Female & 0.750 & $0.467-1.205$ & $1.412(1)$ & 0.235 & - & - & - & NS \\
\hline Age & 0.898 & $0.782-1.031$ & $2.332(1)$ & 0.127 & & & & \\
\hline \multicolumn{9}{|l|}{ Ethnicity } \\
\hline Malay & 1.00 & & & & & & & \\
\hline Chinese & 1.719 & 1.131-2..613 & 6.430 & 0.011 & - & - & - & NS \\
\hline Indian & 2.521 & $1.244-5.108$ & 6.588 & 0.010 & - & - & - & NS \\
\hline Others & 1.531 & $0.469-4.992$ & 0.498 & 0.480 & & & & \\
\hline \multicolumn{9}{|l|}{ Type of institution } \\
\hline Public & 1.00 & & & & 1.00 & & & \\
\hline \multicolumn{9}{|l|}{ Year of study } \\
\hline 1 & 3.671 & $1.532-8.799$ & $8.507(1)$ & 0.004 & 3.953 & $1.511-10.337$ & $7.850(1)$ & 0.005 \\
\hline 2 & 1.101 & $0.557-2.178$ & $0.077(1)$ & 0.781 & - & - & - & NS \\
\hline 3 & 2.054 & $1.331-3.171$ & $10.557(1)$ & 0.001 & 1.980 & $1.243-3.154$ & $8.259(1)$ & 0.004 \\
\hline 4 & 1.00 & & & & 1.00 & & & \\
\hline \multicolumn{9}{|l|}{ Current CGPA } \\
\hline$<2.66$ & 1.00 & & & & & & & \\
\hline $2.67-3.66$ & 2.57 & $0.711-9.276$ & $2.073(1)$ & 0.150 & - & - & - & NS \\
\hline$>3.66$ & 2.78 & $0.728-10.586$ & $2.234(1)$ & 0.135 & - & - & - & NS \\
\hline \multicolumn{9}{|c|}{ Source of funding for tuition fees } \\
\hline PTPTN loan & 1.00 & & & & & & & \\
\hline PSD scholarship & 0.482 & $0.236-0.986$ & $3.991(1)$ & 0.046 & - & - & - & NS \\
\hline MARA scholarship & 0.663 & $0.306-1.438$ & $1.083(1)$ & 0.298 & & & & \\
\hline Self-fundings & 0.924 & $0.580-1.473$ & $0.110(1)$ & 0.740 & & & & \\
\hline
\end{tabular}


Table VI: Factors that may influence students' preference in pursuing a career in the pharmaceutical industry (continued)

\begin{tabular}{|c|c|c|c|c|c|c|c|c|}
\hline & \multicolumn{4}{|c|}{ Univariate analysis } & \multicolumn{4}{|c|}{ Binary logistic regression } \\
\hline & $\begin{array}{c}\text { Crude } \\
\text { OR }\end{array}$ & $95 \% \mathrm{Cl}$ & $\begin{array}{l}\text { Wald's } x^{2} \\
\text { (df) }\end{array}$ & $\begin{array}{c}p- \\
\text { value }\end{array}$ & $\begin{array}{c}\text { Adjusted } \\
\text { OR }\end{array}$ & $95 \% \mathrm{Cl}$ & $\begin{array}{c}\text { Wald's x } \\
\text { (df) }\end{array}$ & $\begin{array}{c}p- \\
\text { value }\end{array}$ \\
\hline Yes & 1.00 & & & & & & & \\
\hline No & 0.807 & $0.480-1.358$ & $0.651(1)$ & 0.420 & & & & \\
\hline Duration of industry placement & 0.995 & $0.984-1.005$ & $0.995(1)$ & 0.319 & & & & \\
\hline Knowledge $^{+}$ & 1.009 & $0.904-1.125$ & $0.024(1)$ & 0.877 & & & & \\
\hline Attitude $^{\ddagger}$ & 1.198 & $1.135-1.264$ & $42.709(1)$ & 0.000 & 1.196 & $1.130-1.266$ & $38.119(1)$ & $<0.001$ \\
\hline Perceived syllabus" & 0.980 & $0.953-1.008$ & $2.013(1)$ & 0.156 & - & - & - & NS \\
\hline
\end{tabular}

OR, Odd ratio; $\mathrm{Cl}$, confidence interval; NS, Non-significance; CGPA, Cumulative Grade Point Average; PTPTN, National Higher Education Fund; PSD, Pharmaceutical Service Development; MARA, People's Trust Council. ${ }^{+}$On career options in the pharmaceutical industry; ${ }^{\ddagger}$ Towards pursuing a career in the pharmaceutical industry; ๆIn an undergraduate degree course related to the pharmaceutical industry.

\section{Discussion}

This study evaluates the career preferences of pharmacy students in Malaysia. Hospitals, community pharmacies, and primary healthcare clinics were the three most preferred careers, and only $38.8 \%$ of students considered the pharmaceutical industry as one of their top three preferred career options. In the current study, the percentage of students who preferred working in the pharmaceutical industry increased from $21.3 \%$ to $38.8 \%$ when compared to the previous study by Hassan and colleagues (2010). This may be due to the recent government policy change which allows graduates to conduct their one-year Provisional Registered Pharmacist (PRP) training at non-government institutions such as community pharmacies, pharmaceutical industries, and research universities (Pharmaceutical Services Programme, 2018). With the introduction of this new policy, current pharmacy students may have been more exposed to potential career opportunities in the industry, thus increasing their interest in the field.

The current study found that salary is no longer a priority in choosing a pharmacy career which is similar to the findings by Hassan and colleagues in 2010 , as students chose work-life balance, working environment, and job security as factors that influenced their career preferences after graduation. This might be due to the awareness of the high salary received by pharmacists at the entry point of practice, regardless of which career path they choose, when compared to other job options. Pharmacists are among the highest paid jobs at the junior level in Malaysia, receiving a monthly salary of up to RM 3600 (Jobstreet.com, 2017). The flexible working schedule was also ranked as the least important factor in this study as students may have known that most career options in pharmacy usually have non-flexible working hours and may require overtime and being on-call.

Students' knowledge of career options in the pharmaceutical industry was found to be good.
Nevertheless, they were unaware of the roles of pharmacists in medical affairs, which include delivering clinical information and forming good relationships with key players in the healthcare industry, developing clinical study protocols and research (Albert, 2017). This may be because the students were not familiar with the terms used, or the practices were not commonly exposed to students in the curriculum. In terms of attitudes, although the majority were aware of the potential for good career advancements such as promotions and training in an industrial setting, many provided neutral answers for providing a work-life balance, difficulty in securing a job, and being unable to utilise clinical knowledge. The latter corresponds to the previous study by Kirby-Smith and colleagues (2007), which reported that the desire for patient contact is the main reason for the lack of interest regarding working in the pharmaceutical industry. Students may not be aware that there are opportunities for clinical knowledge utilisation and patient contact should they be involved in clinical drug development, such as clinical trials and pharmacovigilance (Josse et al., 2016). The current study also found that the syllabus had a positive impact on the students' knowledge about the job scope of a pharmacist in the pharmaceutical industry. However, there was no significant association between knowledge and students' attitudes towards career opportunities in the pharmaceutical industry.

The majority also believed that they received enough emphasis on pharmaceutical industry subjects during their undergraduate study, which contrasts with previous findings from the United Kingdom and Saudi Arabia (Wilson et al., 2006; Saleh et al., 2015), where universities were thought to put more emphasis on clinical knowledge than pharmaceutical sciences, which may have influenced students' career preferences. In Malaysia, universities are required to fulfil the syllabus requirements set by the Pharmacy Board (PBM), which includes providing balanced minimum credit hours for all 
core disciplines/subjects (Pharmacy Board Malaysia, 2007). In line with the PBM's requirements on the delivery of broad-based pharmacy education for the degree programme to meet an increasing experience in the practice of pharmacy in various settings, including industrial pharmacy (Pharmacy Board Malaysia, 2018), the majority of the students reported receiving adequate industrial training and educational visits in the syllabus. Furthermore, despite the fact that the PBM requirement did not state that a pharmaceutical industry placement was required, the current study found that the majority of students had it as a compulsory attachment in their academic programme.

The types of institutions, year of study, and attitude scores influence students' preferences when choosing the pharmaceutical industry as their career path. Students from private universities are more likely to prefer working in the pharmaceutical industry, which is similar to the findings of Hassan and colleagues (2010). This may be due to the fact that a preference for a career in the pharmaceutical industry relates to students' attitudes toward it. It is not known why pharmacy students in private universities have better attitudes toward careers in the pharmaceutical industry, and future studies may wish to explore this further. The students' attitudes toward careers in the pharmaceutical industry can be improved through mentoring systems with pharmacists in the industry. Mentoring systems would provide opportunities for students to understand the nature of the work and be guided in the qualifications and skills required for the position (Hartman et al., 2014). In addition, offering elective courses focusing on the pharmaceutical industry was reported to maybe help increase student preference through interest development in working in the pharmaceutical industry (Hartman et al., 2014; Nakagomi et al., 2016). It is believed that the pharmaceutical industry training offered in such courses may help to improve students' attitudes towards a career in the pharmaceutical industry.

In terms of years of study, the final year students may be less likely to prefer working in the pharmaceutical industry than the first- and third-year students because they had experience in clinical training, which usually occurs during later years of the study, which may be personally rewarding as they have direct contact with the patients (Carter and Segal., 1989). The authors believed that students should be provided with the opportunity to learn and experience various hands-on pharmaceutical industrial training, specifically involving direct patient contact, such as in clinical drug development. Pharmacists in the pharmaceutical industry may also be required to play important roles in promoting their career path by providing placement for attachment and internship training, collaborating with universities in teaching and learning, and mentoring students to promote the field.

This cross-sectional study was limited to a particular time frame; hence it may not reflect the changes or predict future students' preferences, knowledge, and attitudes toward careers in the pharmaceutical industry. In addition, this study included students from different years of study with different levels of exposure to the syllabus, industrial training, and clinical placements. This study overcomes this by exploring students' career preferences in the pharmaceutical industry according to their year of study.

\section{Conclusion}

Students' preferences towards pursuing careers in the pharmaceutical industry are still low compared to other areas of practice. The type of institution, year of study, and attitude scores were found to influence students' preferences regarding careers in pharmaceutical industries. Lack of contact with patients was found to be the leading cause behind pharmacy students having negative attitudes towards working in the pharmaceutical industry. Hence, increasing exposure to pharmaceutical industry careers that involve patient contact and clinical knowledge application are needed to improve students' attitudes towards pursuing a career in this field.

\section{Acknowledgements}

The authors would like to thank the students who have participated in the study and academics who have helped by sharing the survey link with their students.

\section{References}

Albert, E. (2017). Medical affairs: a growing career path. Pharmacy Times (online). Available at: https://www.pharmacytimes.com/publications/career/2017/ careersfall2017/medical-affairs-a-growing-career-path

Berhanu, T., Vijender, S., Vijeta, G. (2019). Factors influences pharmacy students' to elect pharmacy field and their future career desire. International Journal of Pharmacy and Pharmaceutical Research, 16(1): 316-335

Carter, E.A., Segal, R. 1989. Factors influencing pharmacists' selection of their first practice setting. American Journal of Hospital Pharmacy, 46(11), 2294-2300. https://doi.org/10.1093/ajhp/46.11.2294

Bursac, Z., Gauss, C.H., Williams, D.K., Hosmer, D.W. (2008). Purposeful selection of variables in logistic regression. Source 
Code for Biology and Medicine 3:17.

https://doi.org/10.1186/1751-0473-3-17

Farnen, K. (2020). How much do pharmacists that work in pharmaceutical companies earn? Chron (online). Available at: https://work.chron.com/much-pharmacists-workpharmaceutical-companies-earn-31175.html. Accessed 8 September 2020

Hanna, L.A., Askin, F., Hall, M. (2016). First-year pharmacy students' views on their chosen professional career. American Journal of Pharmacy Education, 80(9), 150.

https://doi.org/10.5688/ajpe809150

Hartman, R., Blustein, L., Morel, D., Davis, L. (2014). A pharmaceutical industry elective course on practice experience selection and fellowship pursuit by pharmacy students. American Journal of Pharmaceutical Education, 78(6), 126. https://doi.org/10.5688/ajpe786126

Hasan, S.S., Kwai, Chong D.W., Ahmadi, K., et al (2010). Influences on Malaysian pharmacy students' career preferences. American Journal of Pharmacy Education, 74(9), 166. https://doi.org/10.5688/aj7409166

Institute of Labour Market Competition and Analysis (2013). A Study Of Manpower Requirement In The Healthcare SubSectors In Malaysia. Available at:

https://www.ilmia.gov.my/index.php/en/component/zoo/ite m/a-study-of-manpower-requirement-in-the-healthcare-subsectors-in-malaysia. Accessed 2 Nov 2021

Jobstreet.com. (2017). Salary report (online). Available at: https://www.jobstreet.com.my/announcement/FTP/salaryreport2019v1.pdf

Josse R.T., Chris V.S., Lucia, S. and Luciano, S. (2016). Job and career opportunities in the pharmaceutical sector. In Taosheng, C. and Sergio, C.C. (Ed.) Special topics in drug discover. IntechOpen (online). Available at:

https://www.intechopen.com/books/special-topics-in-drugdiscovery/job-and-career-opportunities-in-the-

pharmaceutical-sector. Accessed 9 April 2018

Kirby-Smith, J., Portlock, J. \& Brown, D. (2007). Investigation of student views on industrial pharmacy. Pharmacy

Education, 8(1), 7-11.

https://doi.org/10.1080/15602210701875333

Los Angeles Research Group (2018). Pharmaceutical \& medicine manufacturing market research (online). Available at: http://www.laresearchgroup.com/pharmaceuticalmedicine-manufacturing.html. Accessed 24 May 2018

Mahmoud, S.A. (2018). Undergraduate pharmacy students' motivations, satisfaction levels, and future career plans. Journal of Taibah University Medical Sciences, 13(3), 247-253. https://doi.org/10.1016/j.jtumed.2018.03.004

Malaysian International Halal Showcase (2018). Halal pharmaceutical: a new frontier (online). Available at: http://mihas.com.my/halal-pharmaceuticals-a-new-frontier/. Accessed 5 April 2018

Malaysian Investment Development Authority (2016). Pharmaceuticals (online). Available at:

http://www.mida.gov.my/home/pharmaceuticals/posts/. Accessed 15 March 2018
Malaysian Investment Development Authority (2018). Guide on pharmaceutical industries in Malaysia (online). Available at:

https://www.mida.gov.my/home/administrator/system_files /modules/photo/uploads/20181026183702_SIB_Pharmacueti cal_2018.pdf. Accessed 9 April 2020

Mikulic, M. (2020), Pharmaceutical market: worldwide revenue 2001-2019. Statista (online). Available at: https://www.statista.com/statistics/263102/pharmaceuticalmarket-worldwide-revenue-since-2001/. Accessed 8 September 2020

Nakagomi, K., Hayashi, Y, Komiyama, T. (2016). Survey of attitudes toward career choice among pharmacy students at a private university. Pharmacy Education, 16(1), 146-157

Performance Management \& Delivery Unit (PEMANDU) (2013). EPP 3: Malaysian pharmaceuticals (online). Available at: http://etp.pemandu.gov.my/Healthcare-@-Healthcare_EPP_3-

;_Malaysian_Pharmaceuticals_\%E2\%80\%93_Increasing_Local _Generic_Manufacturing_for_Exports.aspx. Accessed 15 March 2018

Pharmaceutical Association of Malaysia (2016). Industry overview (online). Available at: http://www.phama.org.my/index.cfm?\&menuid=17

Pharmaceutical Services Programme Ministry of Health Malaysia (2018). List of training premises for provisionally registered pharmacist (PRP) (online). Available at: https://www.pharmacy.gov.my/v2/en/content/list-trainingpremises-provisionally-registered-pharmacist-prp.html. Accessed 15 December 2018

Pharmacy Board Malaysia (2018). Standards on approval and recognition of pharmacy programme (online). Available at: https://www.pharmacy.gov.my/v2/sites/default/files/docum ent-upload/standards-approval-and-recognition-pharmacyprogramme-2018.pdf

Saleh, G., Rezk N.L., Laika, L., Ali, A., El-Metwally, A. (2015). Pharmacist, the pharmaceutical industry and pharmacy education in Saudi Arabia: a questionnaire-based study. Saudi Pharmaceutical Journal, 23(5), 573-580.

https://doi.org/10.1016/j.jsps.2015.02.019

Savage, L.M., Beall, J.W., Woolley, T.W. (2009). Factors that influence the career goals of pharmacy students. American Journal of Pharmacy Education, 73(2), 28. https://doi.org/10.5688/aj730228

Ubaka, C.M., Ochie, U.M. \& Adibe, M.O. (2103). Student pharmacists' career choices: a survey of three Nigerian Schools of Pharmacy. Journal Pharmacy Practice, 11(3), 49155. https://doi.org/10.4321/S1886-36552013000300005

Wilson, K., Jesson, J., Langley, C., Hatfield, K. \& Clarke, L. (2006). Pharmacy undergraduate students: career choices and expectations across a four-year degree programme. Royal Pharmaceutical Society of Great Britain (online). Available at: https://pharmacyresearchuk.org/wpcontent/uploads/2012/11/Pharmacy_undergraduate_student s_career_choices_and_expectations.pdf

World Health Organization (1994). The Role of Pharmacist in the Healthcare System (online). Available at: https://apps.who.int/medicinedocs/pdf/h2995e/h2995e.pdf 